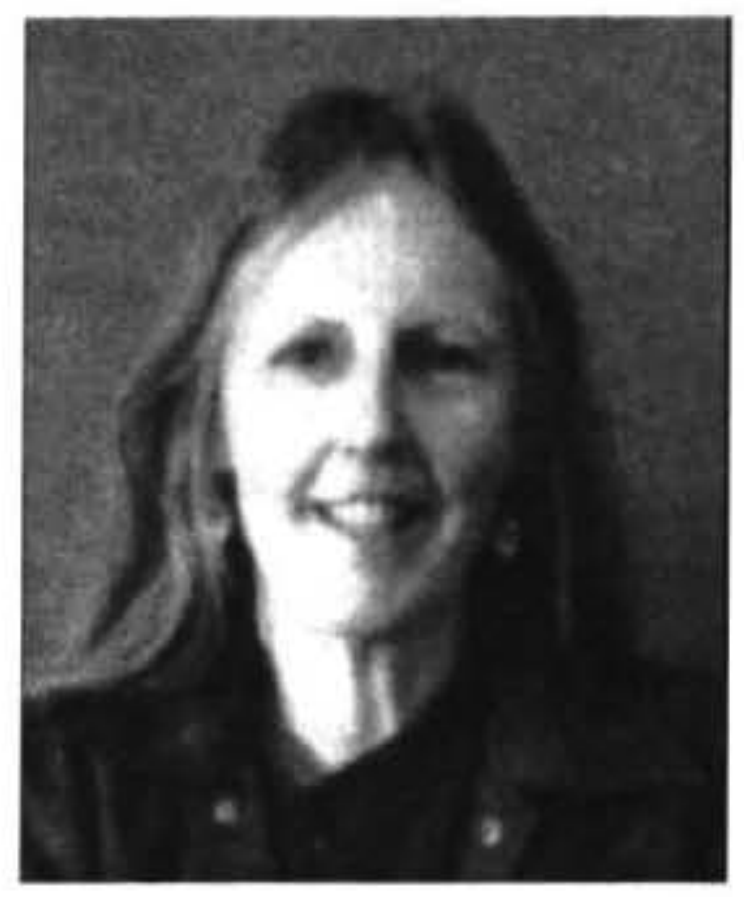

\title{
WOMEN TEACHERS TALK ABOUT THEIR CHANGING WORK
}

\author{
Janet Bedggood
}

School of Communication Studies
Auckland University of Technology

\begin{abstract}
This paper advances a Marxist critique to consider the way the position of women teachers in the state sector is being reproduced under the pressure of reform. It analyses interviews with women teachers in the early childhood sector to evaluate their responses to questions over the impact of government reform in education on the nature of their work and their own activity in their unions to resist the reforms, against other evidence and opinion on the effects of state restructuring in education. The paper investigates whether women teachers see their struggles against the reforms as a struggle to overcome their own vulnerability as workers - particularly against traditional perceptions that their teaching was merely an extension of their domestic labour.
\end{abstract}

Keywords: Teachers, women

Restructuring by the New Zealand state in the 1980s and 90 s, was intended to reverse the downward trend in capital accumulation, or profitability. This restructuring involved a transformation of state sector employment. I was interested whether state sector reforms posed a threat to the economic advances achieved by women in the postwar period, given that the expansion of women's paid employment coincided with the expansion of the state sector where women employees were concentrated in the 'caring' jobs. In particular, I was interested in the education sector reforms that were designed to cut costs in state delivery of education and the effect of these reforms on women teachers.

This paper looks at an aspect of a case study of women teachers across all education sectors. The case study is based on interviews with key informants whose responses were tested against other evidence and opinion on the effects of state restructuring in education. The period that the informants were asked to reflect on, was a period of intense change in education. Under the pressures of change, how did women teachers see themselves?

Historically, teaching has been a socially acceptable occupation for women because it was seen as an extension of their caring domestic role (see Bedggood, 1997). In the interviews I wanted to test the extent to which teaching was seen in this way by the informants themselves compared with their commitment to teaching as workers. So the informants were questioned to ascertain where they positioned themselves in relation to the demands of their domestic labour and their wage labour. I tried to establish their patterns of work and possible movement in and out of employment, as well as their attitudes to work/ their commitment to the job.
The informants were questioned to elicit their knowledge about the education reforms particularly those which affected their sector and the effects of those reforms. I was interested to see whether there was a correlation between their knowledge of the reforms and their participation in organised resistance to the reforms and the consequences of the reforms. I expected some relationship between these variables because the informants were selected on the basis of their activism in their unions. I wanted to establish their commitment to collective action as a possible measure of politicization. This involved testing my proposition that education unions traditionally functioned like craft unions and whether under the pressure of events their union activity matched an industrial union model.

Historically members of craft unions depended on their skill to gain remuneration and protect their relatively privileged position as workers. They relied on their union leadership coming to an accommodation with sympathetic employers to achieve this. Industrial unions tried to achieve better conditions through collective action, to act in the wider interests of workers and be aware of how these interests were opposed to employer interests (Bedggood, 1999).

This element was important in considering whether women's union consciousness was developing into classconsciousness. This is consistent with Gramsci's 'contradictory consciousness' where inherited commonsense understandings conflict with a consciousness developed from action which can lead to class consciousness (Gramsci, 1971: 333).

This paper focuses on one part of this research project, a small group of women teachers in early childhood education. 


\section{The Early Childhood Education Sector}

The primacy of women as mothers/domestic labour is most transparent in the treatment of teachers and policies for the early childhood sector where children are youngest and the workforce is highly feminised. The ideology of 'mother' is evident in a number of measures. Provision seen as complementary to mothering was given the highest level of support historically. Part-time providers like kindergartens and playcentres were at the top of the hierarchy while fulltime childcare received the lowest funding. Childcare was seen as serving the needs of the labour market (Mitchell, 2000) which went against the idea of mothering as woman's primary vocation. It was as if women who put their children in care should not be rewarded by the caregivers receiving the same levels of funding as that given to the centres who catered for the children of those who devoted themselves to full time mothering. Podmore (1996) sees the recent recognition of the need for 'greater flexibility of services' is a recognition that mothers in paid work and their children deserve high standards of provision. But Podmore notes that the idea that early childhood services should accommodate parents' changing patterns of paid work, continues to be questioned (see Podmore, 1996: 20)

The key policy document of the reforms in early childhood, Before 5, increased state support to private for-profit operations offering 'choice' and 'equity' which fits Podmore's argument. However, the apparent 'equity' was exposed as dubious, first as a cover for reducing funding to kindergartens and second, as undermining education through the lack of safeguards in the allocations to private centres. The problems that quickly appeared were problems that became familiar in other sectors. There was little accountability and many 'autonomous' private centres pocketed the money and made no improvements. Mitchell (2000) terms this approach to the early childhood sector as "pure market" because in the for -profit centres, the profit went to the owner of the business and not into providing an education service.

Another consequence of the flattening out was it undermined effort to match the provision for other education sectors. Instead, the state matched down rather than up. As a model for education reform, early childhood faced the greatest challenge of restructuring.

Early childhood centres were more vulnerable to reform because they were never fully state funded. Their reliance on community fund raising made for a 'cake stall' approach to funding operational costs, indicating both the marginality and the domestic labour associations embedded in the sector.

As well as being undervalued in levels of funding historically, childcare was undervalued in terminology, being described as providing 'care' while the other early childhood services were described as providing 'education'. This distinction was collapsed by teachers themselves who argued that the separation of care and education was not viable when all services offered both education and care. The current terminology "early childhood educators' used by the Ministry of Education to describe all early childhood workers, is an important gain for the status of teachers in the 'care' institutions, and for the status of mothers of children using these centres that does not undermine their position as paid workers who are entitled to quality of early childhood education for their children.

However, the flattening out of funding shows that the blurring of care and education can also undermine the professional contribution of early childhood teachers. For example, Treasury (1987) denied that the education children received from the teachers in kindergartens was anything more than children got from their parents. In privileging parents as educators and parental involvement as a key factor in children's learning, Treasury endorsed early childhood work as work that mothers do anyway. This argument is problematised when they refer to some parents as unable to make informed decisions regarding children's' pre-school experience. Parents are not invariably proficient and themselves need education from professionals. This contradictory approach underpins the Parents as First Teachers Scheme (PAFT) which was set up in 1990 by Lockwood Smith, Minister of Education. Smith (quoted in McNaughton, 1992) claimed the policy would "assist and support parents in their natural role as their child's first teachers". Yet the establishment of the scheme suggests that parents were not doing such a good job naturally, and needed to improve their task as teachers.

The 1991 cuts in government funding were directed at under 2 year olds and coincided with the promotion of PAFT which got substantial funding. This was seen as a diversion of public money away from the traditional professional providers into a new scheme that privileged parents as educators. Thus, it appeared as another policy calculated to undermine public provision of ECE and the professionalism of the teachers and keep women at home. Many mothers of young children could not afford the fees for ECE because the government's new fee regime undermined low waged parents' ability to access the centres. At the same time mothering at home was encouraged through full subsidies. This can be seen as the ultimate in privatisation, an attempt to take ECE out of the public sphere and back into the private sphere. It represents pressure from the state to erode socialised domestic labour and reconstitute it as private domestic labour in the household.

Early childhood educators have defended the importance of training and fought to retain and promote it. Their arguments encompass the benefits to children's development of having teachers who "think and reflect on their own practices (Farquhar, 1994) and "stretch children's thinking"(Mitchell, 2000). I sought to test the respondents' commitment to their work as something that was different from what any mother/parent could do. 
Although the state reforms met various degrees of resistance, the early childhood sector was 'done over' in the sense that reforms were trialed before they were introduced in other sectors. The sector was susceptible to reform due to a range of factors. Importantly, because it was never fully incorporated into the state sector it was not able to defend itself invoking historical custom and practice as a state service. The leverage in bargaining for workers in a non-compulsory sector was limited compared with the disruptive effects of worker action, such as withdrawal of labour, in the compulsory sector. Other contributing factors were the traditional lack of militancy of the workers and the highly feminised nature of the workforce.

How is feminised vulnerability measured? It can be linked to the general patterns of participation in waged work, which show women as lower paid and having poorer conditions and generally lower status than men (see Statistics New Zealand, 1999:83-106). Women struggle against conditions of disadvantage which generate social expectations of women's status. I am not arguing that compliance is an innate characteristic of women, but that traditional expectations of appropriate behaviour act as a powerful social control to constrain militancy. In my interviews I was testing respondents who were active in their unions in pursuing change, to see if they held onto conventional perceptions of what was acceptable behaviour, or even essentialist behaviour, for women. Were there strategies or predispositions to behave in certain 'feminine' ways? Did they see their work as gendered in nature?

\section{Care v. Education}

One of the pivotal issues around state provision has been the question of care and education. The tensions between different groups of early childhood workers was evident in the reluctance for care workers and kindergarten teachers to come together in one union in 1986. This was a traumatic event for many kindergarten teachers. Their professional self-image of themselves as kindergarten teachers was upset and many thought they would be lowering themselves to form a union with childcare workers who were carers rather than educators. A kindergarten teacher, Dorothy (not her real name), comments on this:

\section{... our union decided to join [the EC Union] and a lot of kindergarten teachers found it difficult. Many of them left because they thought we were lowering ourselves, and on reflection we did....in those days they weren't trained and horrific things were happening in their centres.}

Dorothy is reflecting the desire of many kindergarten teachers to protect their skills against the contamination that a marriage with childcare workers would bring. This reaction can be interpreted as that of a 'craft' union defending their own skills.
Meg Moss, a trained childcare worker, recognised that kindergarten teachers' fears had some validity but she put a more optimistic perspective on the amalgamation as benefiting the whole sector:

\section{A lot of kindergarten teachers knew nothing about childcare and childcare people didn't know about kindergarten...There was a lot of resentment on different bases ... kindergarten teachers thought childcare people did a second-class job and if they were all lumped together, kindergarten teachers would be brought down...they were professional teachers and childcare workers were not the same breed}

Despite their recognition that childcare teachers were an 'inferior breed', both Moss and Dorothy worked hard to improve the standards for childcare workers. The union did play a role in protecting the interests of childcare workers and improving their access to training. These moves can also be seen as an attempt to protect skilled workers against the erosion of their skills by relatively unskilled workers, in the terms of a craft union mentality.

In defending their skills, kindergarten teachers were challenging social perceptions that their work was essentially a nursemaiding role, not a professional service. They continued to be apprehensive about government policy which appeared to attempt to undermine their conditions of work and their professionalism. They saw their exiting from the state sector under the controversial State Sector Amendment Act 1997 as "part of the plan to make them the same as childcare workers" (Moss, 2000) and reduce their funding. However, kindergartens have maintained their high level of funding in relation to childcare centres.

This hierarchy of status is reflected in the education sector overall. The most feminised areas with the youngest students have the lowest status. As well as wanting to disassociate themselves from childcare workers lest they be tainted by their lower status, in some contexts it was expedient for kindergarten teachers to blur the distinction between themselves and primary teachers. Dorothy recalls experiencing this negativity towards kindergarten teachers outside the union and had learned not to tell people that she was a kindergarten teacher: "I'd just say I was a teacher because I knew the flak I would get - if I said I was a kindergarten teacher they'd say 'Oh my God, why?" Even within the union there was overt hostility. When she attended her first NZEI conference she defended her kindergarten role against a disparaging male primary teacher. Linda Mitchell, NZEI worker, sees this as part of a hierarchy of regard:

It is the under-valuing of women - a feeling that anyone can look after young children. Teachers in early childhood can't possibly require the same qualifications and can't 
possibly do such a complex job as teachers in primary and secondary schools. And primary teachers have the same...In the fight for pay parity and the fight for recognition often its the group above you that's the most vociferous about their job being more complex than your job (Mitchell, 2000).

Again, this demarcation of jobs on the basis of complexity fits into the pride in skill and the protection of the enhanced conditions that the skill brings that is the hallmark of the way a craft union defends its status.

As well a demarcating themselves against childcare workers, kindergarten teachers protected their professionalism against naturalistic ideas that work with small children was merely an extension of mothering. Dorothy was very conscious of what she knew and did, that made her a professional educator:

\begin{abstract}
I've worked with people that aren't trained and you have to be so careful. It's their communication, the way they talk to people...they just don't know how to facilitate learning...If a parent comes to you and asks you questions about how their child's developing, you want to give them encouragement...and then you can go into areas where the little ones may need improvement...Someone who hasn't got the training, hasn't got that knowledge...[of]...the basics of child development (Dorothy, 1999).
\end{abstract}

\section{Organisational Pragmatism}

There was also some opposition from early childhood teachers to joining the NZEI although generally their members were pragmatic. They realised that another union amalgamation was necessary because even their combined union was too small to have any real clout with employers. Dorothy commented that Ken Douglas, then President of the CTU, had said they were too small to negotiate any longer and they should join the wharfies! Within NZEI, my informants were enthusiastic about their membership in terms of the union's ability in negotiations. The larger union brings more weight to negotiations with more financial backing and more experienced negotiators. NZEI is valued for their professional expertise; for their advice on how to avert problems such as handling dreaded Education Review Office (ERO) visits and for their work as policy strategists. They comment knowledgeably on government policy such as the Green Paper and the White Paper. Dorothy expresses her admiration at the breadth of their work; "the union is not just there to bail you out, the amount of work the NZEI do is incredible. They have fingers in every pie".

These advantages relate to the bureaucratic operation of the union which is often seen as 'the union', especially in the craft union model. However, I am interested in the members' participation in the union. Do they shape union policy and tactics? To what extent is it a democratic union of the members as well as for the members?

About $80 \%$ of kindergarten teachers are unionised and fewer are organised in childcare because it is a relatively difficult sector to organise, particularly for childcare workers. They are more isolated, lower paid and less able to afford union fees and have less time to attend union meetings which occur during their hours of work. Kindergarten teachers are isolated from one another because there are only two or three teachers in each kindergarten. When their kindergarten union was separate, they organised union meetings so several groups of teachers could get together like primary teachers who organised themselves in syndicates of several schools. Organisation is easier for secondary teachers who organise branches within each school and tertiary teachers whose branch also covers the institution they work in. These are not the only level of organisation that is a factor in union cohesion and effectiveness. Both the non-compulsory sectors have lost their national contracts while the compulsory sectors have fought and retained them in the period.

Although my informants are impressed with the NZEI and recognise the practical benefits of operating within a big union they have reservations about their involvement. These centre on a loss of identity as early childhood educators. For example, "the name went and there was nothing in the name [NZEI] to acknowledge that early childhood was there" (Dorothy, 1999). Moreover:
You don't get many early childhood people attending branch meetings. My own attendance has dropped off because I find some of the issues for primary teachers boring and I am not with a branch of my own colleagues that I have got a personal history with (Moss, 2000).

Conversely, there seemed to be a negative reaction of primary teachers to issues affecting early childhood teachers:
I became involved in the [area] Auckland branch of NZEI and the chairperson wanted to just pay me off [when] I suggested we needed to spend money to get early childhood workers on board...
I can't go along with this but I'll give you the money.
Fine. I said I didn't have a problem and we'd give him the results, which we did...we got people on board (Dorothy, 1999).

These comments suggest that the amalgamation of KTA and ECWU in 1990 has helped develop a community of interest within the early childhood sector while the later amalgamation with NZEI in 1994, has not generated the 
same commonality to date. The struggle for pay parity between the two sectors may help forge a community of interest. Certainly, my respondents were conscious of the necessity for survival in the face of a government attempting to destroy unions.

\section{Managing Restructuring}

One of the concerns of my informants to emerge from the interviews, was the introduction of a new sort of manager to oversee the reforms, particularly bulk funding. In a calculated move, government undermined worker strength with the imposition of new management structures through all the education sectors. Government attempted to do this under the cover of 'community control' in the primary and secondary sector but a large part of the pre-primary sector was already nominally community run.

Bulk funding was the mechanism for stricter financial control. This was attractive to some kindergarten and union officials. Mitchell (2000) was positive about bulk funding being the method of delivering the funding but critical of the fact "it was not securely tagged for teachers' salaries". Lloyd Falk, the director of the Wellington Kindergarten Association argued against the system on these grounds too. He claimed the bulk funding system for kindergarten teachers was unfair and should be like the primary and secondary sector bulk funding where wage increases translate to increased grants ( NZ Herald: 1995).

But bulk funding meant restricted funding. Within the constrictions of the budget the KTA moved to restrict and undermine teachers' professional autonomy. According to Dorothy there were budgetary restrictions on her hiring relievers and she heard that the KTA were reluctant to employ well-qualified staff who would cost more. Cathy Wylie's research (1993) on the effects of bulk funding on kindergartens nationally, confirmed the rumours Dorothy heard. Nearly half the headteachers in Wylie's survey reported that more untrained relievers were being used in session time. In addition, they said that they were no longer allowed to bring relievers in during non-contact hours. When they were permitted to hire relievers, there were added difficulties in getting them. Potential relievers were reluctant to work with the reduced pay rates and travel allowances arising from the 1992 national contract (Wylie, 1993: 21).

The managers appointed to implement the policies were focussed on accounting not teaching. Problems between management and staff proliferated. For example, in a dispute in 1994, Auckland kindergarten teachers were reported as being upset about extra work imposed on them:

The Auckland Kindergarten Association says urgent cost-cutting is needed to avoid a deficit this year of more than $\$ 400,000$.

A plan by the association to keep its 98 kindergartens open for an extra two and a half days in August and two more in
December will attract more government funds.

But teachers say they have not had a pay rise for more than four years and should not have to bear the brunt of deficiencies in Government bulk-funding.

The association's new general manager, Mrs Jan Jameson, agrees that the funding formula is deficient...She acknowledged that extending class sessions would be hard on teachers, but said her organisation had no choice (Dearnaley, 1994)

According to Dorothy, one new manager was exceptionally bad for teachers. Her job was to improve the Association's finances, but she did not understand what was required for kindergartens because she isolated herself from them. "She made sure she never went near a kindergarten, she never knew the problems" (Dorothy, 1999).

She brought in a new regime with 'totally bizarre' new rules. She stopped teachers' staff meetings. She made them notify sick leave to the Association instead of the kindergarten. She cancelled all other leave including bereavement leave. She broke away from the national Association in December 1994 when the Auckland kindergarten employers walked out of national pay talks.

Dorothy recollects that when the new contracts came through, they were aimed at destroying unions. This new regime was viewed by staff as overtly political. There were rumours that John Luxton (Associate Minister of Education) was involved "because if Auckland fell over, what would happen to rest of the country" (Dorothy, 1999). A Spectrum Radio New Zealand documentary on kindergartens reported that the government saw the new Auckland Association as a model for the rest of the country (Spectrum, 1995). Luxton visited Dorothy's kindergarten several times.

Teachers interviewed by Moss (1999: 102-106) reported that although they had strong opinions over kindergarten management, they felt they had no forum to express these and they had no say over fiscal decisions. They said that they were marginalised by their association. Although parents had an opportunity to become involved in the management of kindergartens very few did. Thus, there was limited involvement from the 'community' in management despite the government rhetoric.

This management control typifies the managerialist-based restructuring occurring throughout the public sector, including other education sectors (see Martin, 1991).

\section{Bulk Funding as Lower Funding}

Kindergarten teachers did not recognise the dangers of bulk funding at the time it was introduced into kindergartens, although it was already a reality in some childcare centres. Moss, who was then a childcare supervisor, was invited to 
speak to a meeting attended by kindergarten teachers on a teacher release day in Auckland in 1991, to forewarn them of the dangers of accepting bulk funding:

I was asked how bulk funding worked for us and I told them the only way it worked for the centre I was in, was we all accepted for four weeks of the year we had no pay, because bulk funding doesn't cover the holidays...it was a struggle at Christmas, in January when you had four weeks of no money. I prepared these wonderful overheads and put them up and said this is how it works, don't accept it. Under no circumstances accept bulk funding...It did not make any difference, they accepted bulk funding. I felt at the time kindergarten teachers were remarkably ignorant of the implications of policy change...they were cocooned, they were all very safe Iin their conditions of work]...I felt as a childcare worker I was extremely aware because we had to be aware - we were out on a limb and the kindergarten teachers were really cosy...

Moss' comments point to the way that kindergarten teachers views reflected their position of relative privilege within the early childhood sector. However, once bulk funding had been put in place, Moss saw the kindergarten teachers' attitudes changing in line with their change in circumstances:
...because of the air of change, kindergarten teachers are more aware of political policy and they may have to fight it...they are not complacent

This change in attitude can be measured by the increase in militancy, in strike action.

Wylie's research into the effects of bulk funding showed that no senior teachers thought that the change to bulk funding benefited kindergartens (Wylie, 1993: 26). Teachers reported substantial increases in their workloads:. This was apparent for my respondents:

\section{I have to spend more time administering this kindergarten. There is more paperwork, more bureaucracy, and more responsibility as head teachers. There is less professional support than there was a few years ago (Moss).}

Dorothy felt the lack of professional support when she was having problems with a difficult group of boys. She was dissatisfied both with the quality of advice she could call on and her inability to reduce numbers as a way of resolving the problem:
...prior to bulk funding in the good old days, we used to have what we called 'senior teachers'... they had the expertise.... they'd

observe [the situation] then they would say, don't take any more in the morning group until you've settled this group, and that's what they should have done this time. But you see, I' $m$ not allowed to do that because of the funding. It immediately means I lose funding (Dorothy, 1999).

Moss saw the requirement for full attendance as having more impact on kindergartens in poorer areas, like the one she runs. She has strategies to juggle the possibility of rolls fluctuating in order to keep the centre operational:
I know the significance of having an empty place... I know I have to have systems in place to ensure we have 45 children enrolled. The only way we can do it in this community is by over-enrolling, by carrying a number of additional enrolments. The downside of that is, what if they all turn up on the same day - 50 children when I've got 45 places? If we were funded directly it wouldn't be an issue and we would be able to offer a higher standard of service because I would only enroll 45 children.

Wylie summarises the dominant themes in the comments made by senior teachers, as, "roll increases and the pressure to keep rolls full, have increased the size of the groups children are working in. In the research literature, group size has long been associated with differences in quality in early childhood centres" (Wylie, 1993: 24). These concerns are echoed by my respondents. Wylie argues that the pressure to match roll numbers with funding formulae may lead to more uniformity in what kindergartens offer, reduction in the quality of delivery and probably the demise of poorer kindergartens where children are in greatest need of high quality early childhood education (Wylie, 1993: 30).

Wylie's (1993) study showed the gap between poor and rich kindergartens widening, resulting in limited access and reduced quality of experience for children in poorer areas. Moss reflects this dedication to equity in provision in public education system under pressure:

The children who most need kindergartens are likely to be the poor attenders because they don't have a car, they don't have a phone, they don't have regular income. So we try to accommodate people who have sporadic attendance.

Moss sees these children as likely to need more attention from their teachers:

I think our children need a high adult to child ratio because we have got a lot of children who don't speak English. We've got refugee children, we've got children with special needs, we've got children with very low exposure to literacy and numeracy in the home circumstances.

\section{Union Militancy}

Cook (1985:206) sees a contradiction in the development 
of early childhood education. It was dependant on the work of women, which meant "struggling against the definition...of the presumed needs of women and children". I find more evidence that the historic gains for ECE were well tied into conventional ideas of women's proper role. Women pushed not necessarily to promote their own rights as workers but to advocate for children:

\section{Kindergarten teachers could be relied on to stand up for their rights, I think because it's tied up with the rights of children that you've got to fight for children who can't fight for themselves (Moss, 2000).}

By emphasising the needs of children, Moss presents teachers' activism as altruistic - they are concerned about children's interests, rather than motivated by any self interest as workers. This conforms to what Judith Duncan (1996) calls the dominant discourse in the teacher campaigns around their negotiations in 1992. This discourse is encapsulated in the phrase 'for the sake of the children'. Duncan interpreted a range of media coverage and union promotional material as depicting kindergarten teachers' central concern being the welfare of children. This discourse draws on notions of women as mothers and carers while overlooking their role as teachers.

If we take Duncan's discourse approach and look at coverage of kindergarten teacher issues in the New Zealand Herald in 1994, the 'children come first' paradigm is not a prominent feature of coverage. Kindergarten teachers used tactics associated with industrial unions and the newspaper stories reflect this. They report on kindergarten teachers in terms of work related issues, the views of contending parties and their actions. The dominant theme of coverage is money, mainly around teachers' pay but covering various aspects of funding to kindergartens whether in terms of money lacking for kindergarten repairs or injections of government funds. Teachers pay issues emphasise low pay rates. For example:

\section{The strike by 1600 teachers closed about 580 kindergartens and affected 46,000 pre- schoolers. \\ A spokesperson for the Educational Institute, Cynthia Slowley, said parents, the public and many employers had responded tremendously to the teachers' predicament. The institute would continue to push for an immediate 4 per cent pay rise for teachers and 6 per cent for head teachers to correct low pay and a 'recruitment crisis' in the profession. (Herald, 14/10/94)}

This exemplifies the Herald's focus on industrial issues and worker response in terms of industrial action. Industrial action that may affect children is not depicted as abhorrent activity for a group of women workers as it was in 1982 when teachers threatened to close the kindergarten rolls and the Minister of Education, Merv Wellington accused them of "pseudo-unionism" (Quoted on Cook 1986:206).

How can we assess the potency of the activism of the early childhood sector workers? This was in the context of pressures not only from education reforms, but also the Employment Contracts Act which had a big impact on the sector. The national awards, which set out pay and conditions for all workers, were eventually lost when employers refused to negotiate at a national level. 1,500 workers lost award coverage.

Certainly, kindergarten teachers' militancy intensified through the restructuring in the 90 s. In $199290 \%$ of kindergarten teachers voted to strike if their contract was not settled. Threats of strike action and local strikes continued over a series of drawn out negotiations. This agitation culminated in a national strike in 1996.

My informants were knowledgeable and reflective about the education reforms. Moss came to a different conclusion about the dangers of bulk funding than the union official I interviewed. However, the early childhood worker informants were uniformly enthusiastic about the union and were remarkably uncritical of union positions or practice. Their activism was within the framework of a bureaucratic craft-type union where the union officials directed the line which the members followed. However, there were dissidents within the ranks. The 1995 settlement was rejected by Dunedin teachers who thought their union negotiators had sold them out (Duncan and Rowe, 1996). They could not persuade their co-workers in the rest of the country to support their vote of no confidence.

Are the kindergarten teachers' strikes a measure of union consciousness and politicisation given the uncritical support given by active members? The three strikes she was involved in during negotiations were seen as "highly effective' by Dorothy. But when one occurred at the same time as a father at her kindergarten was made redundant she found it too hard to ask for parent support because she felt she '.'didn't have a case for the parents to support her...here they are being laid off and I'm asking for a pay increase". The father in question was a manager and not a union member. Dorothy was reluctant initially to join a union and only did so because she would have lost her job had she not joined. She joined kindergarten after three years of teaching. Once she joined she could see the benefits, particularly the professional support. So she developed a union consciousness from an initial position that was anti- union. Her responses showed that this consciousness extended to support of childcare workers within the early childhood sector but not beyond that to other workers. Her limited union consciousness contrasts with Moss' more extensive union experience and more expansive consciousness.

\section{A Gendered Sector}

Dorothy referred to kindergarten as a 'female environment' which it is with $99 \%$ of employees female (Dunn et 
al.1992:34). My respondents did not see the association with small children as necessarily making it an exclusively female domain. Men could (and should) be included given the right circumstances. Dorothy saw the inclusion of male teachers as important because their "whole teaching concept is different from female". When pushed on how the difference manifested itself she mentioned the way men organised outside play with a greater use of heavy equipment. She referred to gender difference as inherent rather than learned.

Moss acknowledged that the social perception would be "what real man would be wanting to work with infants and young children?" This perception was affected by the low salaries which precluded male involvement. Moss commented on the low income and the fact that she would not like it to be the sole income for her family. She thought the lack of males in the sector could be overcome by improving the salary dramatically. Better salaries would attract male teachers. Dorothy saw kindergarten teachers' salaries not being enough to support a wife and children. When asked whether women were supporting their families on their own, she replied "but that's different isn't it?" reflecting her acceptance of a gendered salary differential and the conventional notion of the male breadwinner that underpins it.

Another strongly held social perception around men in early childhood is the mistrust and suspicion of males in this role (See Robinson's study quoted in Farquhar, 1994). Both Moss and Dorothy referred to the Christchurch creche case as creating a stigma of sexually predatory males for all male teachers in early childhood education.

How did respondents see their own paid work role in relation to their domestic role? Moss' commitment to her job was tempered by her own priorities as a wife and mother. She admitted that "my family comes before anything else...family responsibilities have an impact on the job I do now". She managed the potential tension between her family and work responsibilities by blurring the separation between home and family; her job was her 'second home' where her family could get involved too.

Moss conflafed this relationship between home and work in another way too:

I was at home looking after my own
children...the government had no interest in
what I was doing at all. Then I went back to
work. I worked in a licensed childcare centre
and took the two children with me and then
I got paid for looking after them because
they were members of the licensed
centre...Suddenly I was getting paid for
looking after my own children.

Moss may be inferring that she should have got paid for her home work, but the argument she is making is based on her belief that the paid work she was doing was the same as the unpaid childcare she did in her own family. Thus, she is feeding into the argument that paid childcare work is the same as the caring that mothers' do at home with their own children.

Despite their commitment to their jobs and activism in their unions, these key informants appear to identify strongly with orthodox gender roles. Their wage work is an extension of their domestic role.

\section{Future Research}

These interviews with early childhood educators are the first stage in a case study of women teachers across all the education sectors. When I assess the results of the other interviews, I will cross reference them to other accounts of the reforms and evaluate the differences between women in different sectors. My preliminary results are indicating that among teachers in the compulsory sector there was a higher level of informed activity opposing the reform, a much livelier, critical approach to union strategies and greater detachment from domestic labour. These results will give me more information to make inferences about the reproduction of women's status in the state sector and perhaps answer some of the questions I have asked.

\section{Notes}

1 It was criticised as an imported scheme which did not take account of equivalent indigenous schemes (Dalli, 1992). It was designed as a major vehicle for educating parents when parent education was a central feature of existing providers such as playcentres. Pihama (1997) criticised the scheme on the basis it was a patronising attempt to impose Pakeha education values on Maori parents.

\section{References}

Bedggood, J. (1997) Women in Traditional Employment: Early Teachers in Primary Education in New Zealand as a Reserve Army of Labour. Proceedings of the $5^{\text {th }}$ Women and Labour Conference, 1995. Macquarie University. (Eds.) Melanie Oppenheimer and Maree Murray: 44-65.

Bedggood, J. (1999) Rank and File Teachers Against their Union Bureaucrats: Towards a Proletarianisation of Teachers. Paper Given to SAANZ Conference, Auckland.

Cook, H. (1985) Early Childhood Education: A Women's Sphere in a Man's World', in Political Issues in New Zealand Education. Codd, J. Harker, R. and Nash, R. (Eds.). Palmerston North: Dunmore Press: 205-216. 
Dalli, C. (1992) Policy Agendas for Children's Lives, New Zealand Journal of Educational Studies. 27 (1): 53-67.

Davison, C. (1997) Kindergartens and Their Removal from the State Sector Act. New Zealand Annual Review of Education. 7: 151-167.

Dearnaley, M. (1994) Kindy Teachers Angry. New Zealand Herald, 29 April.

Dearnaley, M. (1994b) Kindergartens to Defy Work Order. New Zealand Herald, 6 May.

Duncan, J and Rowe, L. (1996) Don't be Too Polite Girls, Don't be Too Polite: Kindergarten Teachers and Employment Contracts. New Zealand Annual Review of Education. 6: 157-179.

Duncan, J. (1996) 'For the Sake of the Children' as the Worth of the Teacher? The Gendered Discourses of the New Zealand National Kindergarten Teachers' Employment Negotiations. Gender and Education, 8(2): 159-170.

Dunn, A, Pole, A. and Rouse, J. (1992) The Education Sector Workforce. Wellington: Ministry of Education.

Easting, S.K. (1992) Early Childhood Services: For Women or for Children? Superwoman Where Are You? Social Policy and Women's Experience. Briar, C. Munford, R. and Nash, M. (Eds.) Palmerston North: Dunmore Press.

Farquhar, S.E. (1994) Qualifications, Gender and Income: Interrelated Issues in the Early Childhood Sector. New Zealand Annual Review of Education. 4: 3955 .

Gramsci, A. (1971) Selections from Prison Notebooks. New York: International Publishers.

Lange, D. (1988) Before Five: Early Childhood Care and Education in New Zealand. Wellington: Department of Education.

Martin, J. (1991) Devolution and Decentralisation. Reshaping the State; New Zealand's Bureaucratic Revolution. Boston, J. Martin, J. Pallot J. and Walsh, P. (Eds.) Auckland: Oxford: 268-296.

May, H. (1992) After 'Before Five': The Politics of Early Childhood Care and Education in the Nineties. Women's Studies Journal. 8(2) : 83-100.

McNaughton, S. (1992) Parents as Teachers: Validated or Evaluated? Parents as Partners: Parents as Educator Papers from the 1991 NZCER invitational seminar, Margery Renwick (Ed,)
Wellington: NZCER.

Meade, A. and Dalli, C. (1991) Review of the Early Childhood Sector. New Zealand Annual Review of Education. 1: 113-131.

Mitchell, L. (1996a) Crossroads- Early Childhood Education in the mid-1990s. New Zealand Annual Review of Education. 6: 79-91.

Mitchell, L. (1996b) The Cost of Quality, unpublished speech to NZEI seminar, 16-17 May.

Mitchell, L. (1992) Current Policy Issues for Women: What has Happened in Early Childhood Education? Women's Studies Journal. 10(2): 97-102.

Moss, M. (1999) Rhetoric to Reality: Early Childhood Education Funding Policy, Master of Education Thesis, Massey University.

Pihama, L. (1997) Policy Constructions: In Whose Interest? A Critical Analysis of Parents as First Teachers in Relation to Maori Education. Education Policy in New Zealand: The 1990s and Beyond. Olssen, M. and Morris Matthews, K. (Eds.) Palmerston North: Dunmore Press: 283-303.

Podmore, V. (1996) Balancing Early Childhood Education and Work. Wellington: New Zealand Council for Educational Research.

Treasury. (1987) Government Management: Brief to the Incoming Government. Education Issues. Wellington: The Treasury: Vol. II

Wells, C. (1998) Future Directions: Shaping Early Childhood Education Policy for the 21st CenturyA Personal Perspective. New Zealand Annual Review of Education: 8: 45-60.

Wylie, C. (1993) The Impact of Bulk Funding on New Zealand Kindergartens. Wellington: NZCER.

\section{Author}

Janet Bedggood

Senior Lecturer

School of Communication Studies

Auckland University of Technology

Private Bag 92006

Auckland

janet.bedggood@aut.ac.nz 